\title{
EFFECT OF Nb ELEMENTCONTENT IN U-Zr ALLOY ON HARDNESS, MICROSTRUCTURE AND PHASE FORMATION
}

\author{
Masrukan K, M. Husna Al Hasa, Jan Setiawan, Slamet Pribadi \\ Centre for Nuclear Fuel Technology- National Nuclear Energy Agency (NNEA) of Indonesia \\ Kawasan Puspiptek, Serpong, Tangerang Selatan, 15314 \\ e-mail: masrukan2006@yahoo.com \\ (Naskah diterima : 10-04-2015, Naskah direvisi: 22-04-2015, Naskah disetujui: 01-05-2015)
}

\begin{abstract}
ABSTRAK
EFFECT OF Nb ELEMENTCONTENT IN U-Zr-Nb ALLOY ONHARDNESS, MICROSTRUCTURE AND PHASEFORMATION. Experiments to determine the effect of $\mathrm{Nb}$ element in the U-Zr alloys on hardness, microstructure and phase formation has been done. The addition of $\mathrm{Nb}$ element would effect the hardness, microstructure and phase which formed. The U-Zr-Nb alloy was made with the variation of $\mathrm{Nb} 2 \%, 5 \%$ and $8 \%$ by melting in an electric arc melting furnace that equipped with water cooling and the argon atmosphere. The U-Zr-Nb alloy to be cut divided to some testing, such as hardness test, microstructure, and phase analysis. Hardness testing was done by Vickers hardness testing equipment, microstructure by an optical microscope, and diffraction pattern by XRD and phase analysis was done by GSAS. Hardness testing results showed that the addition of $2 \%$ to $5 \% \mathrm{Nb}$ elementin $\mathrm{U}-\mathrm{Zr}$ alloys will increased in hardness, but the addition of $\mathrm{Nb}$ element over $5 \%$ the hardness was decreased. Observations the microstructure showed that the addition of $2 \%$ to $5 \% \mathrm{Nb}$ element, grains were formed from fine into coarse. Phase analysis for diffraction pattern showed that the phase changedfrom aU and $\mathrm{yU}$ $(\mathrm{Zr}, \mathrm{Nb})$ at $2 \% \mathrm{Nb}$ to be $\mathrm{aU}, \mathrm{\gamma U}(\mathrm{Zr}, \mathrm{Nb})$ and $\delta 1\left(\mathrm{UZr}_{2}\right)$ phase at $5 \%$ and $8 \% \mathrm{Nb}$. Phase changes was followed by changes in its compositions. The composition of $\mathrm{aU}$ at $2 \% \mathrm{Nb}$ was $40 \%$ increased to $81 \%$ at $5 \% \mathrm{Nb}$ and decreased to $3.9 \%$ at $8 \% \mathrm{Nb}$. The composition of $\mathrm{\gamma U}$ decreased from $59,86 \%$ to $14,91 \%$ with increased $\mathrm{Nb}$ from $2 \%$ to $5 \%$ and further increased to $52,74 \%$ at $8 \% \mathrm{Nb}$.
\end{abstract}

Keywords : Nb element, U-Zr alloy, hardness, microstructure, and phase analysis.

\section{ABSTRACT}

PENGARUH KADARUNSUR Nb PADA PADUAN U-Zr-Nb TERHADAP SIFAT MEKANIK, MIKROSTRUKTUR DAN PEMBENTUKAN FASA. Percobaan untuk mengetahui pengaruh kadar $\mathrm{Nb}$ pada paduan U-Zr-Nb terhadap sifat mekanik, mikrostruktur dan pembentukan fasa telah dilakukan. Penambahan unsur Nb diduga akan mempengaruhi sifat mekanik, mikrosruktur, ketahanan korosi dan fasa yang terbentuk. Penambahan unsur Nb ke dalam paduan U-Zr dimaksudkan untuk memperluas daerah fasa gamma yang stabil dan memperbaiki ketahanan korosi. Mula-mula dibuat paduan U-Zr-Nb pada variasi $\mathrm{Nb} 2 \%, 5 \%$ dan $8 \%$ dengan cara melebur di dalam tungku peleburan busur listrik yang berpendingin air dan dalam media gas argon. Paduan U-Zr-Nb yang terbentuk dipotong-potong untuk dikenai beberapa pengujian, diantaranya uji mekanik (kekerasan), mikrostrutur, dan fasa yang terbentuk. Pengujian kekerasan dilakukan dengan menggunakan peralatan uji kekerasan Vickers, mikrostruktur dengan menggunakan mikroskop optik, dan fasa dengan menggunakan XRD dan analisis fasa menggunakan program GSAS. . Hasil pengujian kekerasan menunjukkan bahwa penambahan $\mathrm{Nb}$ pada paduan U-Zr dari 2\% menjadi 5\% mengakibatkan kenaikan kekerasan, tetapi kemudian kekerasan turun pada penambahan di atas 5\% Nb. Pengamatan mikrostruktur yang terbentuk memperlihatkan bahwa pada penambahan unsur $\mathrm{Nb}$ sebesar dari $2 \%$ menjadi 5\% maka terbentuk butir dari kasar menjadi halus. Dilihat dari pembentukan fasa, terjadi perubahan yakni dari $\alpha U$ dan $y U$ pada $2 \%$ $\mathrm{Nb}$ menjadi fasa $\alpha U, \gamma U$ dan $\delta 1$ (UZr2) pada $5 \% \mathrm{Nb}$ dan $8 \% \mathrm{Nb}$. Perubahan fasa tersebut juga diikuti dengan perubahan prosentase fasa yaitu pada $2 \% \mathrm{Nb}$, dimana fase $\alpha U$ yang semula $40 \%$ mengalami kenaikan menjadi $81 \%$ pada $5 \% \mathrm{Nb}$ dan selanjutnya turun menjadi $3,9 \%$ pada $8 \% \mathrm{Nb}$. Untuk fasa yU terjadi penurunanyang semula $59 \%$ menjadi $14 \%$ pada $5 \% \mathrm{Nb}$ dan selanjutnya naik menjadi $32 \%$ pada $8 \%$. 
Katakunci :Logam Nb, U-Zr,sifat mekanik, mikrostruktur, fasa.

\section{INTRODUCTION}

Development of nuclear fuel for research reactor wasto achieve high density fuel, in that case the fuel had higher mass uranium in per unit volume of the fuel.Pure uranium metal used as nuclear fuel had disadvantage in fabrication process to nuclear fuel element as final product.Pure uranium should alloyed with another metals to improve its properties. Metals such as Al, $\mathrm{Si}, \mathrm{Mo}, \mathrm{Zr}, \mathrm{Nb}, \mathrm{Ti}$ are commonly used as alloying metal to improve the properties of uranium metal ${ }^{[1]}$. Besides in the form of metal alloys, the uranium fuel also in the form of oxide $\mathrm{U}_{3} \mathrm{O}_{8}$ and nitride $(\mathrm{U}-\mathrm{N})$. Alloys U-Alx/Al, oxide $\mathrm{U}_{3} \mathrm{O}_{8} / \mathrm{Al}$ and metal alloys $\mathrm{U}_{3} \mathrm{Si}_{2} / \mathrm{Al}$ has been used, but they had low density of around $2,3 \mathrm{gU} / \mathrm{cm}^{3}$ for U-Alx / $\mathrm{Al} ; 3.2 \mathrm{gU} / \mathrm{cm}^{3}$ for $\mathrm{U}_{3} \mathrm{O}_{8} / \mathrm{Al}$ and $\mathrm{U}_{3} \mathrm{Si}_{2} / \mathrm{Al}$ for $4,8 \mathrm{gU} / \mathrm{cm}^{3[2]}$. Based on these facts, the Argonne National Laboratory on behalf of the RERTR Programme presented, by the end of 1996, an irradiation plan for new fuels allowing theoretically to reach densities up to 8 or $9 \mathrm{~g} \mathrm{Ut} / \mathrm{cm}^{3}$. The Uranium alloys used for these fuels were supposed to be a $Y$ stabilised phase. For really higher densities compared to $\mathrm{U}_{3} \mathrm{Si}_{2}$, uranium molybdenum (U-Mo) and uranium niobium zirconium $(\mathrm{U}-\mathrm{Zr}-\mathrm{Nb})$ alloys were mainly considered ${ }^{[3]}$. Hence it is necessary obtaining higher density nuclear fuel.At the present, effort to develope the nuclear fuel with high density still continues with research and development alloys $\mathrm{U}-\mathrm{Mo}, \mathrm{U}-\mathrm{Zr}$ and $\mathrm{UN}$ as nuclear fuel.

Besides the U-Mo alloy and the U-N, the $U-Z r$ alloy was selected as the candidates of nuclear fuel that had high density. Selection the U-Zr alloy was based on several reasons, including: have a low neutron absorption cross section, have a fairly high density, have good corrosion behavior. Development of the U-Zr alloys has been done by varying the $\mathrm{Zr}$ element at
$2 \%, 6 \%, 10 \%$, and $14 \%$ and has been characterized and selected to be made into a mini fuel element plate $(\mathrm{FEP})^{[3]}$. Manufacturing and characterization on the $\mathrm{U}-\mathrm{Zr}$ mini $\mathrm{FEP}$ at $6 \% \mathrm{Zr}$ (U-6Zr) showed acceptable results and meet the requirements as nuclear fuel. Further prepared for irradiation test in nuclaer reactor using $U$ enrichment at $19.75 \%{ }^{[3]}$. Research manufac-ture of fuel alloy $\mathrm{U}-4 \mathrm{Zr}-2 \mathrm{Nb}$ with density of $3.17 \mathrm{~g} / \mathrm{cm}^{3}$ has been done, and was based on the irradiation test, neutronic properties, and the fabrication was found that the alloy is good enough as a fuel when the density of the alloy reaches $8,0 \mathrm{~g} /$ $\mathrm{cm}^{3[4,5]}$.

In the reactor, the nuclear fuel will undergo the changes as a result of conditions the reactor (the environmental) that affect it's performance in the reactor. To improve the performance of $\mathrm{U}-\mathrm{Zr}$ alloys fuel, it is necessary to add another metal element. Metallic elements commonly added were $\mathrm{Mo}, \mathrm{Nb}, \mathrm{Zr}, \mathrm{Ti}^{[6]}$. Bruno, et.al have made U-Zr-Nb alloy powder with hydridingdehydriding method and passivated, resulting U-Zr-Nb powder with anguler morphology and irregular shape ${ }^{[7]}$. An other experiment that observed corrosion on U2.5Zr7.5Nb alloy was conducted by Celiade Afigueiredo et.al. Heating up to 300 ${ }^{\circ} \mathrm{C}$ showed good corrosion resistance, meanwhile, heating up to $600{ }^{\circ} \mathrm{C}$ showed lower corrosion resistance. This behavior can be associated to the phase stability when transition elements were added to uranium $^{[8,9]}$. In ternary phase diagram system, resulted from experiments conducted by Dwight and Mueller can be shown that the phase $\mathrm{yU}(\mathrm{UZrNb})$ will be stable for in the range where the phase $\delta$ (UZr2) were existence at temperatures higher than $700^{\circ} \mathrm{C}$. The solubility of $\mathrm{Nb}$ in phase $\delta(U Z r 2)$ is about $10 \%$ by weight. Phase $\mathrm{\gamma U}(\mathrm{Zr}, \mathrm{Nb})$ can be maintained as metastable phase depends on the cooling 
rate and the concentration of $\mathrm{Nb}$ and $\mathrm{Zr}^{[10]}$.Addition of $\mathrm{Nb}$ influence the properties of U-Zr alloy, such as mechanical properties, microstructureand formed phases.Addition of $\mathrm{Nb}$ in specific limit will increased mechanical properties such as it's hardness. Addition of $\mathrm{Nb}$ more than it should, caused increased it's hardness and made it harder to process should avoided.Alloy hardness correspon-ded to it's microstructure such as grain size and phases. Type and number of phases besides influence the mechanical properties also influence the alloy stability at high temperature.This research aimed to make theU-Zr-Nb alloy on the variation of $\mathrm{Nb}$ and to understand the changes on it's properties.

\section{METODOLOGI}

Uranium, zirconium, and niobium metals which has been cut into pieces placed in the electric arc furnace with argon atmospheric and cooled water to be melting. Alloying metals of $\mathrm{U}, \mathrm{Zr}$, and $\mathrm{Nb}$ was done with varying the $\mathrm{Nb}$ metal, respectively for 2 , 5 and $8 \%$ by weight while the $\mathrm{Zr}$ metal fixed at $6 \%$. Each pair of samples $\mathrm{U}, \mathrm{Zr}$ and $\mathrm{Nb}$ was melted with electric current at $150 \mathrm{~A}$ and remelted for five times which each side done for 3 minutes to ensure achieved homogeneous ingot $\mathrm{U}-\mathrm{Zr}-\mathrm{Nb}$ alloy. The total weight of ingot $\mathrm{U}-\mathrm{Zr}-\mathrm{Nb}$ for one smelting was $10 \mathrm{~g}$. Similarly to the other pairs of samples of $\mathrm{U}-\mathrm{Zr}-\mathrm{Nb}$ done in the same way. The ingots the $\mathrm{U}-\mathrm{Zr}-\mathrm{Nb}$ alloy then cut into pieces to be subject to testing, such as: hardness, microstructure and the phase are formed. Hardness testing is done by using a micro hardness test equipment (Vickers), microstructure by using an Nikon Ephiphot optical microscope, and phase using Panalytical Empyrean X-ray Diffraction (XRD). The phase analysis done by GSAS software from diffraction pattern obtained from X-Ray Diffraction (XRD). The total weight of ingot the $\mathrm{U}-\mathrm{Zr}-\mathrm{Nb}$ for one smelting is $10 \mathrm{~g}$. Similarly, for a pairs of samples of $\mathrm{U}-\mathrm{Zr}-\mathrm{Nb}$ the other was done in the same way.

\section{RESULT AND DISCUSSION}

\section{a. HARDNESS}

Hardness result shown in Figure 1, the microstructure in Figure 2.a, b and c, and the results of testing the phase is shown in Figure 3.a, b and c.

Figure 1 shown the data hardness test, at the higher $\mathrm{Nb}$ content of up to $5 \%$ by weight, then the higher the hardness of 375 into $523 \mathrm{HVN}$, then decreased when the content of $\mathrm{Nb}$ rise at $8 \% \mathrm{Nb}$ alloy. The U- $6 \mathrm{Zr}-8 \mathrm{Nb}$ hardness at 319 HVN.This condition is caused by the addition of $\mathrm{Nb}$ element into the $\mathrm{U}-\mathrm{Zr}$ alloys which form the $\mathrm{U}-\mathrm{Zr}-\mathrm{Nb}$ alloy.During melting $\mathrm{Nb}$ elements form nucleus, and these nucleus would growth become grains. The $\mathrm{Nb}$ element at $2 \%$ relatively remain small to solubility limit compared at $5 \%$.Nucleations at $2 \%$ fewer than $5 \%$ and resulting fewergrains formed. Grain act as an obstacle to dislocation motion, more grains are formed, the movement of dislocations will be more difficult and lead increase hardness. Therefore, the $\mathrm{Nb}$ addition at $5 \%$ into $\mathrm{U}-\mathrm{Zr}$ $\mathrm{Nb}$ alloy leadthe hardness of $\mathrm{U}-\mathrm{Zr}-\mathrm{Nb}$ alloy higher than the addition of $2 \% \mathrm{Nb}$. The addition of $\mathrm{Nb}$ elements exceed $5 \%$ showed hardness decreasing. The hardness decreasing caused by the abundance of $\mathrm{Nb}$ elements in alloys and will slow the formation of grain from the nucleus of the $\mathrm{Nb}$. In other words, the grain growth rate is slower than the speed ofthe nucleation rate for $\mathrm{Nb}$ element addition. Therefore increased $\mathrm{Nb}$ above 5\%, caused the grains fewer. Formed grains fewer caused the movement of dislocations becomes easier and decreased in hardness. 


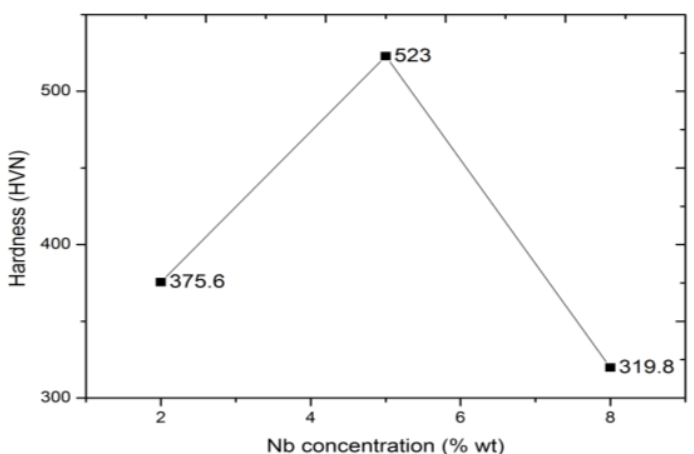

Figure 1. Curve of hardness testing versus percentage of $\mathrm{Nb}$ content

\section{b. MICROSTRUCTURES}

Figure2.a, $\mathrm{b}$ and $\mathrm{c}$ shows the microstructure images of U-Zr-Nb alloy for the addition at $2 \%$ (Figure 2.a) formed grains are not uniform, partly in the form of coarse grains and partly others fine-grained. The grain structure showed the alloy not uniform during melting process. These was caused in arc melting process limited the movement of molten elements during heating. Repetition five times heating with arc melting was done to increased its homogenous compare to once heating. Compared to the $\mathrm{U}-\mathrm{Zr}$ alloys with $\mathrm{Nb}$ addition at $5 \%(\mathrm{U}-6 \mathrm{Zr}-5 \mathrm{Nb})$ as shown in Figure2.b, it's seen that the alloy of $\mathrm{U}-6 \mathrm{Zr}-5 \mathrm{Nb}$ have finer grain size than the alloy ofU-6Zr-2Nb (Figure2.a).This is due to the amount of $\mathrm{Nb}$ element is added to thealloyU-6Zr-5Nb more than $\mathrm{Nb}$ element is added to the $\mathrm{U}-\mathrm{Zr}$ alloys with the addition at $2 \%$ (U-6Zr-2Nb), caused more nucleus were formed if the nucleus were formed higher then the grains were formed higher and finer. However, on the $\mathrm{Nb}$ addition at $8 \%$ which is slightly near to the solubility limit of $\mathrm{Nb}$ in $\mathrm{U}-\mathrm{Zr}$ alloy also show less grains and more coarse than $\mathrm{Nb}$ at $2 \%$ and $5 \%$. The Nb concentration near it's solubility limit in U-Zr alloy only some $\mathrm{Nb}$ can soluble and continues to nucleation and grain growth with $\mathrm{U}-\mathrm{Zr}$ alloy. The othersmall amount of $\mathrm{Nb}$ that can not soluble in $\mathrm{U}$ and $\mathrm{Zr}$ would acted as grain growth restrain of $\mathrm{U}-\mathrm{Zr}$ - $\mathrm{Nb}$ alloy.The grain size value, on the Nbaddition at $2 \%, 5 \%$ and $8 \%$ respectively
$\mathrm{U}-\mathrm{Zr}-\mathrm{Nb}$ alloy had an average grain size at $0,012 \mu \mathrm{m} ; 0.0226 \mu \mathrm{m}$ and $0,013 \mu \mathrm{m}$ or with range from (0.009 to 0.025$) \mu \mathrm{m}$; $(0.013$ to 0.029) $\mu \mathrm{m}$ and (0.006 to 0.02$) \mu \mathrm{m}$ respectively.

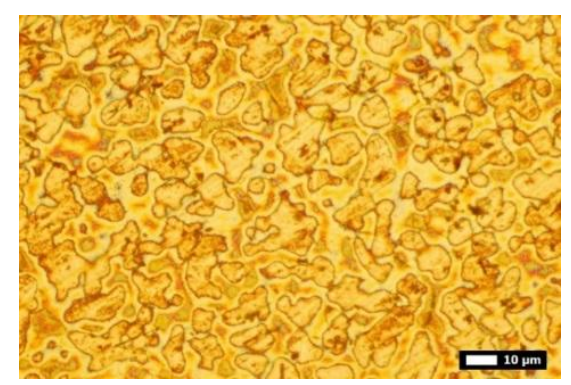

(a)

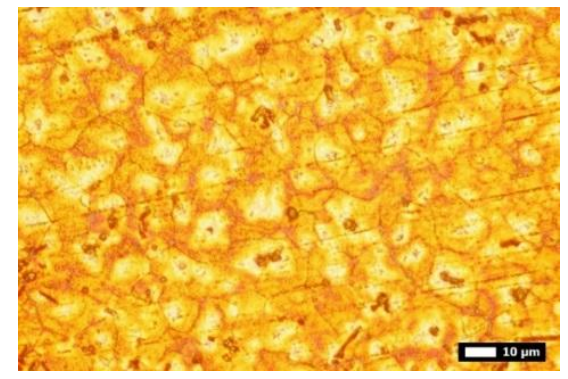

(b)

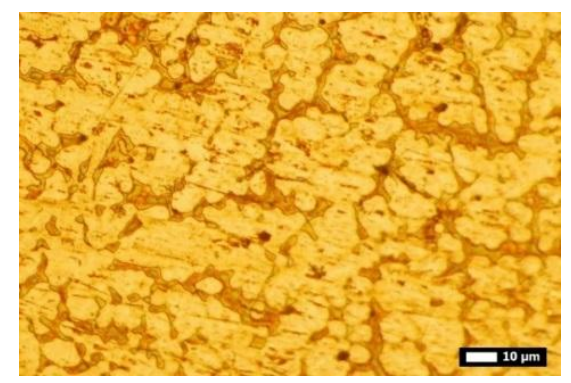

(c)

Figure 2. Microstructure images of $\mathrm{U}-\mathrm{Zr}-\mathrm{Nb}$ alloys.
a. U-6Zr-2Nb,
b. U-6Zr-5Nb, and
c. U- $6 \mathrm{Zr}-8 \mathrm{Nb}$

\section{c. PHASE ANALYSIS}

Powder diffraction pattern showed in Figure $3 a, b$ and c. Figure $3 . a$ is diffraction pattern for U-6Zr-2Nb alloy which indicates that the alloy $\mathrm{U}-6 \mathrm{Zr}-2 \mathrm{Nb}$ have $\alpha \mathrm{U}$ and $\mathrm{yU}$ phases. The $\alpha \mathrm{U}$ phase appears on the $2 \theta$ angles respectively at $35.4^{\circ} ; 38.6^{\circ} ; 52.05^{\circ}$, and $65.01^{\circ}$ with each hkl of $021,111,200$, and 211 , while the phase angle $\mathrm{yU}$ appears on the $2 \theta$ of $35.64^{\circ} ; 59.8^{\circ}$, and $76^{\circ}$ with 
each hkl of $002,200,131$, and 220. The aU phase has orthorhombic structure in space group of $\mathrm{Cmcm}$ with lattice parameters $\mathrm{a}=$ 2.917 (5) $\AA$, $b=5.82$ (1) $\AA$, and $c=5.02$ (1) $\AA$, withdensity at $18.428 \mathrm{~g} / \mathrm{cm}^{3}$. Weight percentage composition of existing $\mathrm{aU}$ phase at $40.14 \%$. The $\mathrm{YU}$ phase has a cubic crystal structure in the space group of $1 \mathrm{~m}-3 \mathrm{~m}$ with lattice parameters $a=3.497 \AA$, density at $18.431 \mathrm{~g} / \mathrm{cm}^{3}$. Weight percentage composition of existing $\mathrm{YU}$ phase at $59.86 \%$. The $\mathrm{U}-6 \mathrm{Zr}-5 \mathrm{Nb}$ alloy consists of three phases, namely phase $\alpha U, \gamma U$ and $\delta 1(U Z r 2)$. The $\alpha \mathrm{U}$ and $\mathrm{YU}$ phases appears at an angle $2 \theta$ and $\mathrm{hkl}$ that the same as in theU-6Zr-2Nb alloy. Similarly, the lattice parameters and thespace group $\alpha U$ and $\mathrm{yU}$ phases also the same as the alloy $\mathrm{U}-6 \mathrm{Zr}-2 \mathrm{Nb}$. The $a \mathrm{U}$ and $\mathrm{YU}$ phases density respectively are at $18.127 \mathrm{~g} / \mathrm{cm}^{3}$ and $18.657 \mathrm{~g} / \mathrm{cm}^{3}$, while the weight percentage compositions of $\alpha \mathrm{U}$ and $\mathrm{YU}$ phases respectively are at $81.80 \%$ and $14.91 \%$. Meanwhile, the phase $\delta 1$ (UZr2) appears withstrong peak at $2 \theta$ angle of $26.67^{\circ}$ and the hkl 001.The $\delta 1$ (UZr2) phase has a hexagonal crystal structure with lattice parameters of $a=6.529(2) \AA$ and $b=$ $3.61(3) \AA$, and density of $9.754 \mathrm{~g} / \mathrm{cm}^{3}$. Weight percentage composition of $\delta 1$ (UZr2) phase at $3.29 \%$

TheU-6Zr-8Nb alloy consists of three phases, namely phase $\alpha \mathrm{U}, \mathrm{\gamma U}$ and $\delta 1$ (UZr2). The $\alpha U$ and $\gamma U$ phases appears at an angle $2 \theta$ and hkl the same as in the alloy $\mathrm{U}-6 \mathrm{Zr}-2 \mathrm{Nb}$ and U-6Zr-5Nb. Similarly, the lattice parameters and the space group $a U$ and $\mathrm{yU}$ phases also the same as the alloy lattice parameter and the space group on the alloy U-6Zr-2Nb andU-6Zr-5Nb. The aU and $\mathrm{YU}$ phases density respectively are at $20.067 \mathrm{~g} / \mathrm{cm}^{3}$ and $19.909 \mathrm{~g} / \mathrm{cm}^{3}$, while the wightpercentage compositions of $\alpha \mathrm{U}$ and $\mathrm{yU}$ phases respectively are at $3.10 \%$ and $52.74 \%$. Meanwhile, the $\delta 1$ (UZr2) phase appears at $2 \theta$ angle of $26.67^{\circ}$ andhkl 001. The $\delta 1$ (UZr2) phasehas a hexagonal crystal structure with lattice parameters $a=6.529$ Åand $\mathrm{b}=3.61$ (3) $\AA$, well as density of 9.607 $\mathrm{g} / \mathrm{cm}^{3}$. Weight percentage composition of $\delta 1$ (UZr2) phaseat $44.16 \%$. The results of this experiment corresponds to an experiment that conducted by Komar Varela, et al (2012), in which the experiment to make $\mathrm{U}-\mathrm{Zr}-\mathrm{Nb}$ alloys obtained of $\alpha \mathrm{U}, \mathrm{\gamma U}$, and $\delta 1(\mathrm{UZr} 2)$ phases $^{[9]}$. The test results of XRD shown that the increase in the $\mathrm{Nb}$ contents shows changes in phases content that $\alpha \mathrm{U}$ and $\mathrm{\gamma U}$ at $2 \% \mathrm{Nb}$ into $\alpha \mathrm{U}, \mathrm{\gamma U}$ and $\delta 1$ (UZr2) phases at $5 \%$ and $8 \% \mathrm{Nb}$. The phase changes was followed by the weight percentage composition change in the phase at $2 \% \mathrm{Nb}, a \mathrm{U}$ phase which was originally $40 \%$ increased to $81 \%$ at $5 \% \mathrm{Nb}$ and further decreased to $3.9 \%$ at $8 \%$ $\mathrm{Nb}$.The $\mathrm{yU}$ phase decrease which was originally $59 \%$ to $14 \%$ at $5 \% \mathrm{Nb}$ and further increased to $32 \%$ at $8 \% \mathrm{Nb}$. Meanwhile, the $\delta 1(\mathrm{UZr} 2)$ phase found in $5 \% \mathrm{Nb}$ increased in $8 \%$ to $44 \% \mathrm{Nb}$. At Figure 4 it was showed the curve correlation beetwen $\mathrm{Nb}$ concentration versus phase concentration ( $\alpha, y$ dan ठ).

At $5 \% \mathrm{Nb}$, the UZrNb alloy hardness is higher than the $2 \%$ and $8 \% \mathrm{Nb}$. This is due to $5 \% \mathrm{Nb}$ the $\mathrm{U}-\mathrm{Zr} \mathrm{Nb}$ alloy containing alpha-phase highest compared to $2 \% \mathrm{Nb}$ alloy and $8 \% \mathrm{Nb}$. The phases in three alloys are $\alpha U, \mathrm{YU}$, and $\delta$. Note that the alpha phase having a crystal structure orthorombic, whiley $U$ and $\delta$ phases cubic and hexagonal respectively. At $2 \% \mathrm{Nb}$, the delta phase is very low to be detected by XRD or not formed and tend to form alpha and gamma phase. Alpha phase is due during the cooling process when the change in the gamma phase into alpha phase ${ }^{[11]}$. Increasing concentrations of $\mathrm{Nb}$ to $5 \%$ to encourage the formation of delta phase and by Ghosal, et.al (2014) Nb concentrations of more than $3.5 \%$ will inhibit the formation of beta phase. It also results in a high concentration of alpha phase in this alloy which occurs due to the gamma phase change that occurs as a result of negligent phase during the cooling process. The increase in $\mathrm{Nb}$ concentration to $8 \%$ that 
encourage the formation of more stable gamma phase ${ }^{[11]}$. This is because the temperature for the formation of gamma phase will be lower due to increased concentrations of $\mathrm{Nb}^{[11]}$. In the phase diagram of $\mathrm{U}-\mathrm{Nb}$ and $\mathrm{U}-\mathrm{Zr}$ shown that increasing $\mathrm{Nb}$ concentration will also increase the amount ofdelta phase formed ${ }^{[11]}$.

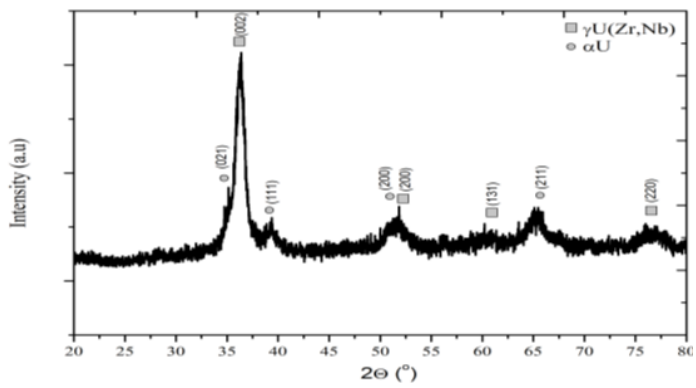

(a)

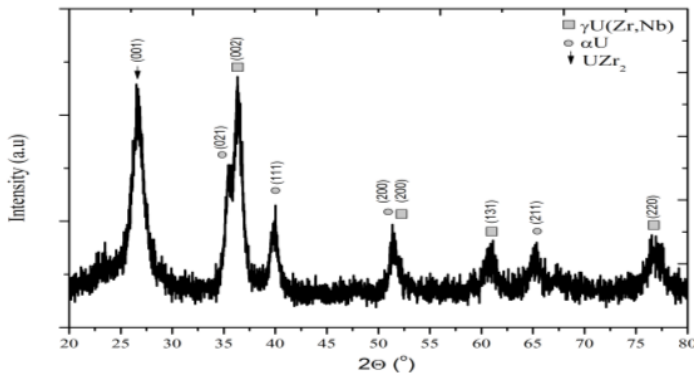

(b)

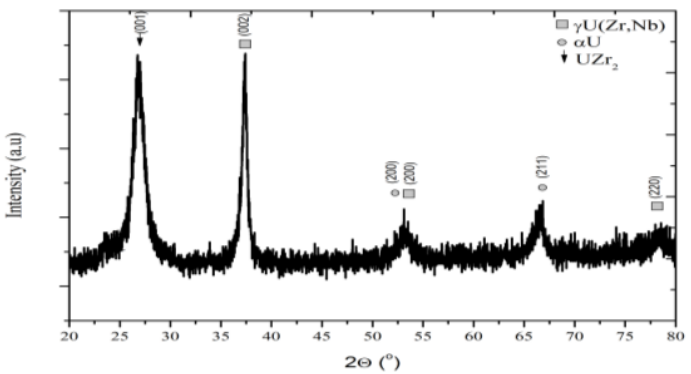

(c)

Figure 3. Diffraction pattern of $\mathrm{U}-\mathrm{Zr}-\mathrm{Nb}$ alloys

(a) U-6Zr-2Nb,

(b) U-6Zr-5Nb and

(c) U-6Zr-8Nb

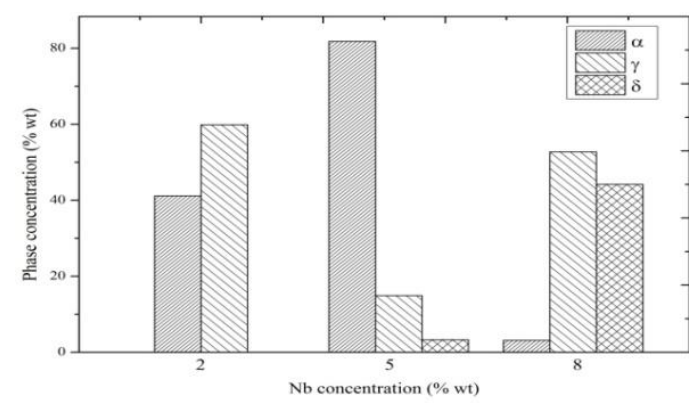

Figur 4. Curva of $\mathrm{Nb}$ cocentration versus phase concentration

\section{CONCLUSIONS}

The results of hardness testing, microstructure and phase analysis of the $\mathrm{U}-\mathrm{Zr}-\mathrm{Nb}$ alloy can be concluded that the addition of $\mathrm{Nb}$ element into the $\mathrm{U}-\mathrm{Zr}$ alloys will increase the hardness of up to $5 \%$ of $\mathrm{Nb}$ content, then decreased at higher $\mathrm{Nb}$ element. The $\mathrm{Nb}$ element addition at $2 \%$ and $5 \%$ shows changes in the microstructure which increasingly fine grain size, but the addition above $5 \%$ the grains become coarse (enlarged). Phase changes occur on the addition of the $\mathrm{Nb}$ content of $\alpha \mathrm{U}$ and $\mathrm{\gamma U}$ at $2 \% \mathrm{Nb}$ into phase $\mathrm{aU}, \mathrm{\gamma U}$ and $\delta 1$ (UZr2) at $5 \% \mathrm{Nb}$ and $8 \% \mathrm{Nb}$. The phase change concentration was followed by content of phase. At $2 \% \mathrm{Nb}$, the the concentration $a \mathrm{U}$ increased from $40 \%$ to $80 \%$. $\mathrm{YU}$ phase at $2 \% \mathrm{Nb}$ decreased from $59,86 \%$ down to $14,91 \%$ and at $5 \% \mathrm{Nb}$ and increased to $52,74 \%$ at $8 \% \mathrm{Nb}$.

\section{ACKNOWLEDGEMENTS}

The author would like to thank to friends who have helped this experiments until finished. Our thanks also convey to Mr. Yatno DA, Yuwono, and Suyoto who have helped this experiments until finished.

\section{REFERENCES}

[1]. A. Ewh, E. Perez, D. D. Keiser Jr, Y. H. Sohn, (2010), Microstructural Characterization of U-Nb-Zr, U-Mo-Nb, and U-Mo-Ti Alloys via Electron, Journal of Phase Equilibria and 
Diffusion, June 2010, Volume 31, Issue 3, pp 216-222.

[2]. Supardjo, (2011). Development of Uranium-Based Alloy U-Mo As Candidate Nuclear Research Reactor Fuel For Replacing Fuel Dispersion $\mathrm{U}_{3} \mathrm{Si}_{2}$-Al. Proceedings of the National Seminar on Nuclear Energy Development IV. The Center for Development of Nuclear Energy, National Nuclear Energy Agency of Indonesia. ISSN 1979-1208.

[3]. K. Masrukan, Yatno D.A, Suyoto, Slamet P, (2012), Fuel Technology Development Research Reactor, Proceedings of Research Results Nuclear Fuel Element, ISSN No. 0854 5561. Page 25-37.

[4]. Balart, et. Al. (2006). Progress on LEU Very High Density Fuel And Target Developments in Argentina". Proceeding of RRFM, 30 April-3 Mey 2006, Sofia, Bulgaria.

[5]. M.M. Brestscher, J.E Matos,(1996), Neutronic Performance of High Density LEU Fuels in Water Moderated and Water Reflected Research Reactors", ANL, 9700 South, Cass Avenue, Argonne, Illinois, Juli1996.

[6]. Supardjo, (2007). Study of the change process as fuel U-Mo Powder Dispersion U-Mo/Al for a Research Reactor. Proceedings PPI-PDIPTNYogyakarta, July 10, 2007 Accelerator Center and Process Materials-BATAN. ISSN. 0216-3128.

[7]. Bruno M.A, Claudia T K, Wilmar B F, Humberto G R, (2011). Methode For
Preparation Of U-Zr-Nb Alloy Powder Passivation, Proceeding of IPEN, Sao Paolo, 2011, n.1, page 36-41.

[8]. Celia de A Figueiredo, Fabio A Mansur, Ana Maria M Dos Santos, Wilmar B Ferraz, (2014). Corrosion Behavior of Alloy U2.5Zr7.5Nb in Relation to Phase Stability, Proceeding of $10^{\text {th }}$ Symposium on Electro-chemical Methods in Corrosion Research 2012 Brazil, Maragogi- Al 18-23 November 2012 , Centro de Desenvolmen to da Technologia Nuclear (CDTN/CNEN), Av Antonio Carlos, 6627,31270- 901, Belo Harzonte MG.

[9]. H.M. Volz et al., (2007). X-Ray Diffraction Analysis of Aged U-Nb Alloys, Journal of Alloys and Compound, volume 444-445, p.217-225, 2007.

[10]. Komar Varela, Gribaudo L,M., Gonzalez, Arico S.F, (2012). Transformation Behavior of The $\mathrm{YU}(\mathrm{Zr}, \mathrm{Nb})$ Phase Under Continues Cooling Conditions, Proceeding RERTR 2012 $\left(34^{\text {th }}\right.$ International Meeting On Reduce Enrichment For Research And Test Reactor), Avenida General Paz 1499, B1650 KNA, SanMartin, Buenos AiresArgentina.

[11]. K.Ghosal, et.al. (2014). Microstructural Investigation of Uranium Rich U-Zr-Nb Ternary Alloy. Jurnal of Nuclear Materials, 446 (2014) 217-223, Radiometallurgy Division, Bhabha Atomic Centre, Trombay, Mumbai 400085, India. 